\title{
PENGARUH KOMPETENSI GURU, MOTIVASI DAN LINGKUNGAN KERJA TERHADAP KINERJA GURU
}

\author{
Azulaidin \\ Universitas Amir Hamzah \\ azul.aidin@yahoo.com
}

\author{
Enita Rosmika \\ Universitas Amir hamzah \\ Nitarose60nr@gmail.com
}

\begin{abstract}
Abstrak
Penelitian ini bertujuan untuk mengetahui seberapa besar pengaruh kompetensi guru, motivasi dan lingkungan kerja terhadap kinerja guru pada SMP Kartika 1-2 Medan. Penelitian ini menggunakan metode diskriptif kuantitatif dengan menggunakan pendekatan normatif (legal research) untuk data sekunder dan pendekatan empiris untuk memperoleh data primer melalui penelitian lapangan. Populasi dalam penelitian ini adalah SMP Kartika 1-2 Medan, populasi berjumlah 31 guru dalam pengambilan sampel menggunakan teknik probability sampling. Teknik pengambilan sampel yang digunakan adalah dengan teknik Quesioner dengan menggunakan metode Likert Summated Rating.Teknik analisis data pada penelitian ini yaitu menggunakan deskripsi data, uji asumsi klasik, regresi linier berganda, uji t (uji parsial), uji F (uji simultan), dan koefisien determinasi dengan bantuan software SPSS 18 (Statistical Product and Service Solutions). Hasil penelitian menunjukkan bahwa secara simultan kompetensi guru, motivasi dan lingkungan kerja berpengaruh signifikan terhadap terhadap kinerja guru pada SMP Kartika 1-2 Medan. Secara parsial kompetensi guru, movitasi danlingkungan kerja berpengaruh signifikan terhadap kinerja guru pada SMP Kartika 1-2 Medan dan secara parsial kompetensi guru, movitasi kerja dan lingkungan kerja berpengaruh signifikan terhadap kinerja guru pada SMP Kartika 1-2 Medan..
\end{abstract}

\section{: Keyword: Kompetensi Guru, Motivasi, Lingkungan Kerja dan Kinerja} Guru.

\section{PENDAHULUAN}

Sumber daya manusia penting untuk tata kelola organisasi. Manajemen membutuhkan sumber daya manusia sebagai administrator untuk mencapai tujuannya. Output perusahaan sangat dipengaruhi oleh kinerja instruktur. Lembaga atau perguruan tinggi 
sering kali bertujuan untuk meningkatkan hasil kerja guru dengan harapan memenuhi tujuan lembaga. Sekolah diharapkan dapat meningkatkan dan memajukan pendidikan dalam kondisi dan pelatihan yang tinggi akan tugas meningkatkan kinerja siswa.

Guru adalah pentingnya penguatan tata kelola guru bagi tenaga teknis yang memiliki posisi strategis untuk mewujudkan visi penyampaian pembelajaranyang sejalan dengan nilai-nilai profesionalisme dan mewujudkan profesionalisme guru. Peraturan Pemerintah No 74 tahun 2008 tentang guru mensyaratkan perubahan untuk mengakomodasi tumbuhnya tata kelola guru sebagai pendidik profesional dalam rangka perubahannya.

Berdasarkan Peraturan Menteri Pendidikan Nasional Republik Indonesia Nomor 16 Tahun 2007 tentang Jenjang Kualifikasi Akademik dan Kompetensi Guru, disebutkan bahwa guru mempunyai empat kompetensi dasar, yaitu: (1) kompetensi pedagogik, yaitu kompetensi guru, mengontrol pendidikan; (2) kompetensi teknis, yaitu kemampuan menguasai materi pendidikan yang luas dan mendalam yang dipelajari selama pendidikan keterampilan; (3) kompetensi psikologis, yaitu kemampuan guru sebagai anggota masyarakat untuk berinteraksi dan bersosialisasi secara efektif; dan (4) kompetensi profesional yaitu matang, stabil, matang, matang dan jujur.

Untuk keempat kompetensi tersebut, guru dituntut untuk menjalankan tugasnya sebagai pendidik berbakat. Hal ini karena bersekolah dan belajar tidak hanya dimaksudkan untuk membekali anak dengan berbagai jenis informasi dan teknologi (learning to know) dan yang dibutuhkan dalam kehidupannya (learning to do) tetapi pendidikan harus mampu memberikan siswa pengetahuan yang lebih lengkap (learning to know) menjadi dan kesadaran yang lebih jelas dan menghormati orang lain (learning to live together).

\section{Pengertian Kinerja Guru}

\section{LITERATURE REVIEW}

Kinerja (prestasi kerja) merupakan hasil kerja perorangan dalam menyelesaikan kewajiban yang diberikan atas dasar pengetahuan, pengalaman danketepatan. Konsep kinerja adalah tingkat kinerja pekerjaan atau proses untukmemenuhi tujuan, sasaran, maksud dan tujuan perusahaan / instansi ditentukan oleh komposisi perusahaan.

Menurut Jufrizen (2018 : 408) Kinerja merupakan suatu tanda kinerja atau kegagalan seseorang atau kelompok dalam melaksanakan suatu pekerjaan nyata yang telah ditentukan baik oleh organisasi. Prestasi kerja memiliki beberapa faktor, antara lain faktor personal dan faktor non personal.

Menurut Sinambela (2016) Kinerja adalah pencapaian fungsi seseorang, baik kualitas maupun kecerdasannya dalam menjalankan tugas sesuai dengan tanggung jawabnya. Teori ini berhubungan dengan pendapat Ranihusna (2018), Yang 
menyatakan bahwa kinerja tinggi seseorang memiliki ciri-ciri yaitu kewajiban keimigrasian yang tinggi, bertanggung jawab untuk memenuhi beban kerja yang menantang, memiliki tujuan yang realistis, dan berupaya mencapai tujuan tertentu dengan menyusun program kerja.

\section{Faktor - faktor yang mempengaruhi kinerja guru}

Kinerja seorang guru banyak dipengaruh oleh beberapa faktor yaitu kemampuan, lingkungan kerja, peluang untuk meningkatkan keterampilan kerja, upah/gaji, dorongan kerja, peraturan perusahaan.

Adapun uraian dari faktor-faktor tersebut adalah sebagai berikut "menunjukkan bahwa kinerja guru dipengaruhi oleh faktor intrinsik guru (pribadi /individu) atau sumber daya manusia dan faktor ekstrinsik yaitu faktor kepemimpinan, sistem, tim, dan situasional. Faktor-faktor ini didefinisikan sebagai berikut:

1. Faktor pribadi, terdiri dari ilmu, kemahiran, pemahaman, pendidikan, dorongan, dan tanggung jawab yang ada di dalam diri seorang guru.

2. Faktor atasan, meliputi bagian dari hasil dan seorang pimpinan dalam memberikan dorongan, dan semangat kerja kepada guru.

3. Faktor tim, meliputi mutumotivasi yang diberikan oleh sati tim kerja, kepercayaan melalui sesama rekan kerja, kesetaraan, dan keselaranan rekan kerja.

4. Faktor sistem, meliputi sistem kerja, fasilitas kerja yang telah disiapkan oleh pimpinan sekolah, evaluasi organisasi (sekolah) dan budaya kerja dalam organisasi; (sekolah).

Kontekstual (variable situasional), termasuk tuntutan dan perkembangan lingkungan eksternal dan internal.

\section{Pengertian Kompetensi Guru}

Menurut UU No.14 tahun 2005 tentang Guru dan Dosen Pasal 1 Ayat 10, disebutkan menyatakan bahwa: Kompetensi merupakan pengetahuan, kemampuandan sikap yang harus dimiliki, dihayati dan diatur oleh guru atau dosen dalam melaksanakan tugas profesional. Kompetensi tidak hanya dikaitkan dengan keberhasilan seseorang dalam menjalankan tugasnya, tetapi juga berhasilnya bekerja sama dalam tim sehingga tujuan lembaga dapat tercapai sesuai rencana.

\section{Faktor - faktor yang mempengaruhi kompetensi guru}

Berdasarkan Peraturan Pemerintah Nomor 19 Tahun 2005 tentang Mutu Pendidikan Nasional, banyak sekali Ujian Kompetensi Guru yang wajib dimiliki tenaga kependidikan yang mempunyai kompetensi pedagogik, teknis dan sosial. Daftar 
kompetensi yang harus dipelajari instruktur, diantaranya sebagai berikut:

1. Kompetensi Integritas profesional, yaitu kapasitas seorang instruktur untuk memasukkan masalah yang terkait dengan profesionalisme dan dapat ditunjukkan dalam kesediaannya untuk menetapkan tugas, melaksanakan tugas dengan baik, bertujuan untuk mencapai tujuaninstruksional, dan memenuhi fungsinya dalam pembelajaran di kelas.

2. Keterampilan pedagogis, meliputi penguasaan dan pemahaman karakter serta pengenalan kemampuan dan tantangan dalam pembelajaran siswa. Guru juga harus mampu membangun program agar dapat memanfaatkan teknologi dan pengetahuan untuk keperluan pembelajaran membuat model pembelajaran yang menarik.

\section{Pengertian Motivasi}

Motivasi menggerakkan individu untuk mendemonstrasikan tindakan untuk pencapaian tujuan tertentu. Yang muncul dari luar hanyalah perbuatanmanusia, yang mungkin didasarkan pada sejumlah motif. Maklum, inspirasi ini juga tidak mudah dipelajari.

Robbins dalam Wibowo (2012) Motivasi sebagai metode yang mendorongkekuatan, arahan, dan ketekunan seseorang untuk mencapai tujuan. Hanya berdasarkan sejumlah motivasi.

\section{Faktor-faktor yang mempengaruhi motivasi}

Ukuran individu bukanlah inspirasi yang ada pada individu. Motivasi itu sendiri terjadi sebagai akibat dari pengalaman antar pribadi yang ada. Menurut Danim (2010), Ada banyak variabel yang mempengaruhi motivasi, yaitu:

1. Gaya Administrator Kepemimpinan. Kepemimpinan dalam kepribadian yang mengesankan membuat staf di tempat kerja tidak bahagia dan tidak peka.

2. Perilaku manusia. Ada orang yang stagnan dan ada pula yang dinamis.

3. Demikian pula, ada yang memiliki motivasi kerja tinggi dan ada yang memiliki motivasi kerja yang rendah. Motivasi dipengaruhi oleh keadaan dan situasi di luar individu. Bagaimanapun individu itu sendiri adalah hal yang paling pasti.

4. Perilaku manusia. Ada orang yang stagnan dan ada pula yang dinamis. Begitu pula ada yang motivasi kerjanya tinggi dan ada yang motivasi kerjanya rendah. Akan tetapi yang palingmenentukan adalah individu itu sendiri.

5. Jika kriteria terpenuhi, maka kondisi pekerjaan, lingkungan kerja, jarak tempuh dan fasilitas yang tersedia menjadi inspirasi. Namun hal itu akan menghambat semangat jika kondisi tertentu tidak diperhatikan. Jika kondisi yang mendukung terpenuhi, manusia akan bekerja dengan baik. Di sisi lain, jika alasan pendukung yang dia butuhkan tidak ada, pekerja akan menjadi tidak puas. 


\section{Pengertian Lingkungan Kerja}

Kenyataannya korporasi, baik besar, menengah maupun kecil, sama-sama dapat berkomunikasi dengan suasana dimana perusahaan atau organisasi tersebut berada. Dunia itu sendiri sedang berkembang, jadi perusahaan atau perusahan yang akan berkembang adalah organisasi yang biasanya merespon perubahan lingkungan. Sebaliknya jika perusahaan tidak memperhatikan trend dan perubahan dunia sekitarnya maka organisasi akan mengalami masa kegagalan. Lingkungan kerja adalah tempat di mana pegawai melakukan aktifitas setiap harinya.

\section{Faktor yang dapat mempengaruhi lingkungan kerja, adalah :}

1. Menggunakan warna yang tepat pada peralatan dan dinding ruangan, warna akan mempengaruhi kondisi emosional karyawan dan mempertahankan kebahagiaan dalam ketenangan kerja.

2. Kebisingan dapat berdampak buruk pada lingkungan kerja yang tidak tenang atau keras. Dalam menyelesaikan pekerjaan, ketenangan lingkungan kerja sangat bermanfaat.

3. Karyawan membutuhkan pencahayaan yang tepat dan baik di kantor, yang memiliki banyak keistimewaan, seperti lebih mudah dilihat, sehingga memudahkan mereka untuk melanjutkan tugas.

4. Undang-undang pekerjaan dan undang-undang ketenagakerjaan yang konsisten akan berdampak kuat pada retensi karyawan dan keberhasilan dalam pertumbuhan karier organisasi. Untuk mencapai prioritas perusahaan dan tujuan individu dengan percaya diri, pekerja diharapkan untuk melaksanakan tugas mereka.

5. Ventilasi udara yang memadai dari ventilasi udara yang tersedia akan meningkatkan kesegaran fisik karyawan. Desain bangunan juga akan mempengaruhi pertukaran udara.

6. Keamanan, keharmonisan dan relaksasi dapat diciptakan oleh lingkungan kerja yang sehat. Perlindungan yang dimaksud adalah keamanan properti pribadi karyawan.

7. Kebersihan dan konfigurasi ruangan akan mempengaruhi setiap orang dalam bekerja secara tidak langsung, karena jika ruang kerja bersih maka pekerja akan merasa lebih baik dalam melakukan pekerjaannya. Pada kenyataannya, tata letak tempat kerja juga akan mempengaruhi kenyamanan kerja staf.

\section{Indikator Lingkungan Kerja}

Adapun penilaian-penilaian lingkungan kerja menurut Sedarmayanti(2011:46) adalah sebagai berikut: 
1. Dari Data. Untuk setiap pekerja ringan untuk memasuki kantor, diperlukan penerangan. Dengan tingkat pencahayaan yang memadai, kondisi kerja yang bersahabat tercipta.

2. Suhu atmosfer. Temperatur suhu udara di ruang kerja kantor adalah seberapa besar suhu tersebut atau akan terlalu dingin untuk tempat kerja yang menyenangkan suhu di dalam ruangan terlalu tinggi.

3. Suara berisik. Kebisingan adalah derajat kepekaan karyawan yangberdampak pada perilaku karyawan.

4. Penggunaan warna. Penggunaan warna ruangan yang digunakan untukbekerja adalah penggunaan lighting.

5. Ruangan yang dibutuhkan. Ruang untuk berpergian, termasuk alatbantu kerja seperti bangku, lemari tempat duduk, dan sebagainya merupakan lokasi kerja antara satu pekerja dengan pekerja lainnya.

6. Keterampilan kerja. Kesediaan bekerja merupakan situasi dimana bekerja akan menghasilkan rasa aman dan tenang.

\section{RESEARCH QUESTIONS}

Salah satu upaya untuk meningkatkan efisiensi guru adalah dengan tingkatkan keterampilan setiap guru, menginspirasi baik instruktur, staf dan siswa dan peserta didik. Motivasi adalah fenomena yang berperan dalam upaya manusia untuk mencapai hasil dalam hal kekuatan, arah, dan durasi. Jika seseorang merasa gaji perusahaan sesuai dengan yang diharapkan pemberi kerja, maka dapat menginspirasi karyawan untuk meningkatkan kinerja guru atau karyawan.

Sangat penting bagi mereka untuk dapat meningkatkan efisiensi karyawan. Organisasi untuk menemukan apa yang menyebabkan atau menyebabkan prestasi meningkat. Menurut Siagian (2010: 12), efisiensi karyawan dapat dipengaruhi oleh gaji, suasana kerja, budaya tempat kerja, semangat kerja, etos kerja, kepuasankerja, motivasi, kepemimpinan dan motivasi kerja (motivasi). Sekolah harus memiliki guru yang berkualitas untuk mendukung sebuah sekolah, sehingga dapat mendidik dan mengajarkan sesuatu yang berharga kepada siswa dan menjadikan

siswa dan siswanya menjadi individu yang berguna untuk masa depan dan dapat memperoleh semangat dari pengawas dan teman sebaya serta pekerjaan yang menyenangkan dan menyenangkan suasana bagi guru, siswa dan staf sekolah.

Begitu pula jika kompetensi, motivasi dan lingkungan kerja guru baik ataumeningkat maka kinerja guru juga akan meningkat, begitu pula sebaliknya jika kompetensi, motivasi, dan lingkungan kerja guru kurang baik atau menurun maka kinerja guru juga akan meningkat. Guru juga akan berkurang. Kemampuan dan guru kemudian harus lebih berkembang dan yang paling kritis, pengawas harus mampu menginspirasi guru 
untuk menjadi lebih prospektif dan membangun karir yang santai dan damai. agar dapat melaksanakan tugas dan tanggung jawabnya.

Pernyataan ini sejalan dengan hasil penelitian yang dilakukan oleh Maju Siregar (2019) menyatakan bahwa pengaruh Kompetensi Guru, Motivasi, dan Lingkungan Kerja berpengaruh positif terhadap Kinerja Guru. Struktur matematis variabel independen dan dependen dalam melihat pengaruh antar variabel dapat dicapai baik secara bersamaan maupun parsial pada gambar paradigma di bawah ini, tergantung uraian tersebut di atas:

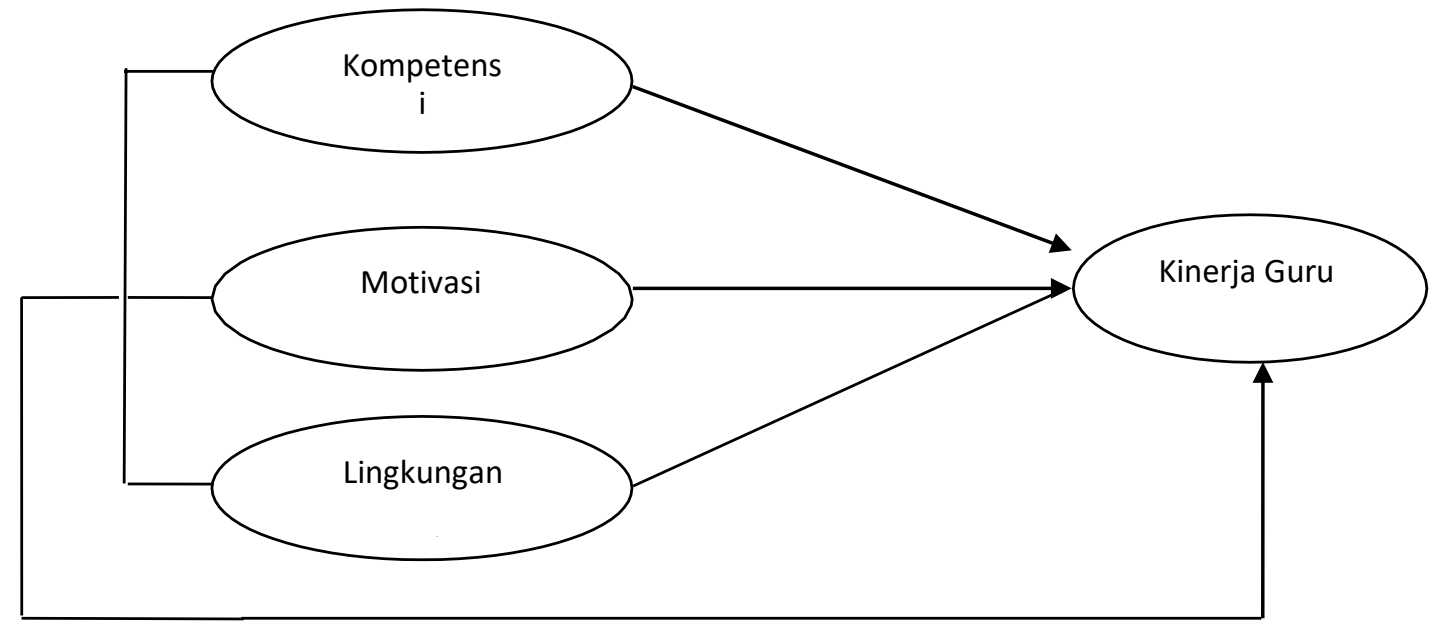

Gambar 1. Paradigma Penelitian

\section{Hipotesis}

Berdasarkan batasan dan rumusan masalah, maka dapat dibuat hipotesis penelitian sebagai berikut :

1. Ada pengaruh Kompetensi Guru terhadap Kinerja Guru pada SMPKartika 1-2 Medan.

2. Ada pengaruh Motivasi terhadap Kinerja Guru pada SMP Kartika 1-2Medan

3. Ada pengaruh Lingkungan Kerja terhadap Kinerja Guru pada SMPKartika 1-2 Medan

4. Ada pengaruh Kompetensi Guru, Motivasi, Lingkungan Kerja secarasimultan terhadap Kinerja Guru pada SMP Kartika 1-2 Medan

\section{METHOD}

\section{Pendekatan Penelitian}

Metodologi kuantitatif yang digunakan dalam penelitian ini menekankan pada interpretasi terhadap data numerik (angka) yang diolah menggunakan teknik statistik. 
Pada dasarnya, dalam analisis inferensial (untuk mengevaluasi hipotesis), metode teoritis dilakukan dan temuan dari hasil difokuskan pada kemungkinan ketidakpastian dalam penolakan hipotesis nol.

Menurut Sugiyono (2010:56) Dimungkinkan untuk mendeskripsikan metode analisis kuantitatif sebagai pendekatan penelitian yang berfokus pada teoripositivisme, yang digunakan untuk menganalisis satu kelompok atau sampel. Pengumpulan data menggunakan metode pengujian, analisis data kuantitatif /statistik untuk mengevaluasi hipotesis untuk menilai pengaruh variabel bebas $\mathrm{X}$ terhadap variabel terikat $\mathrm{Y}$ dan pengaruh yang dekat antara kompetensi guru, motivasi dan lingkungan kerja terhadap keberhasilan guru di SMP Kartika1-2 Medan.

\section{Populasi Dan Sampel}

Menurut Sugiyono (2011: 389) Populasi adalah bidang generalisasi yang terdiri dari item atau subjek dengan atribut dan karakteristik yang ditentukan oleh peneliti dan kemudian diambil kesimpulannya. Guru adalah demografi yang digunakan dalam penelitian ini. Penelitian ini dilakukan di SMP Kartika 1-2Medan dengan total 31 guru.

\section{Sampel}

Menurut Sugiyono (2011: 389) analisis ini merupakan sampel jenuh untuk metodologi pemilihan sampel yang digunakan, dimana semua perwakilanpopulasi dijadikan sampel, termasuk seluruh guru di SMP Kartika 1-2 Medan yang berjumlah 31 guru.

\section{Teknik Pengumpulan Data}

Teknik pengumpulan data yang dilakukan dalam penelitian ini adalah:

\section{Dokumentasi}

Dengan mempelajari, membaca, mereview dan mereview literatur berupa buku, artikel dan publikasi yang berkaitan dengan subjek penelitian, pengumpulan bukti dengan mempelajari catatan dan catatan untuk mendukung penelitian ini.

\section{Kuesioner}

Pendekatan ini dilakukan dengan menyebarkan kuesioner untuk responden secara individu dan segera dikembalikan kepada peneliti dalam bentuk pertanyaan atau komentar. Skala likert dengan formulir 
checklist digunakan sendiri oleh penyidik.

\section{DISCUSSION}

\section{Pengaruh Kompetensi Guru, Motivasi dan Lingkungan Kerja terhadap Kinerja Guru.}

Hasil penelitian yang diperoleh mengenai pengaruh Kompetensi Guru, Motivasi, dan Lingkungan Kerja secara bersamaan terhadap Kinerja Guruadalah hasil uji hipotesis secara simultan yang menunjukkan bahwa dari hasil uji ANOVA (Analysis

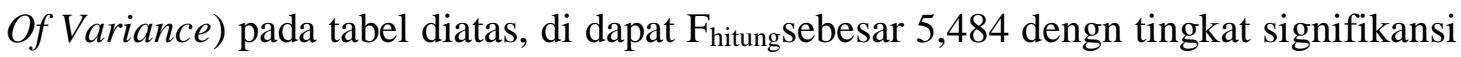
sebesar 0,000, sedangkan $\mathrm{F}_{\text {tabeld }}$ diketahui sebesar 3,35. Berdasarkan hasil tersebut dapat diketahui bahwa $-F_{\text {tabel }}$ lebih kecil sama dengan $F_{\text {hitungdan }} F_{\text {hitunglebih besar sama dengan }}$ $F_{\text {tabel }}(-3,35 \leq 5,484 \geq 3,35)$, sehingga $\mathrm{H}_{0}$ ditolak. Jadi dapat disimpulkan bahwa variabel Kompetensi guru, Motivasi dan Lingkungan Kerja secara simultan berpengaruh signifikan terhadap Kinerja guru pada SMP Kartika 1-2 Medan.

Hal ini berarti bahwa secara bersama baik atau tidaknya Kompetensi Guru, Motivasi, dan Lingkungan Kerja secara bersamaan terhadap Kinerja Guru. Sedangkan tanda positif dari hasil uji menunjukkan bahwa dengan baiknya Kompetensi guru, Motivasi, dan Lingkungan Kerja maka akan terjadi peningkatan pada Kinerja Guru, begitu juga sebaliknya. Kompetensi profesional hal ini sangat relevan karena merupakan penentu kinerja proses pembelajaran dan secara khusus mempengaruhi keterampilan belajar, termasuk pengelolaan kelas, persiapan, perencanaan penyampaian,evaluasi hasil belajar dan kemajuan siswa terhadap kemampuannya.

Motivasi adalah tersedianya faktor penuntun yang merangsang hasrat untuk pekerjaan orang lain sehingga mereka siap untuk berpartisipasi, bekerja secara efisien, dan digabungkan dengan semua upaya mereka untuk mencapai kepuasan. Lingkungan kerja merupakan suatu faktor yang secara tidak langsung mempengaruhi kinerja pegawai. Lingkungan kerja yang kondusif menawarkan rasa sejahtera dan mendorong pekerja untuk bekerja secara maksimal. "Lingkungan kerja berarti seluruh perkakas dan material yang dihadapi, lingkungan sekitar tempat seseorang bekerja, metode kerja, dan pengaturan kerja baik sebagai individu maupun sebagai kelompok" Lingkungan kerja berarti seluruh perkakas dan material yang dihadapi, lingkungan dalam yang dilakukan seseorang, metode kerja, dan pengaturan kerja baik sebagai individu maupunsebagai kelompok. Dalam melaksanakan kewajiban organisasi, lingkungan kerja berpengaruh signifikan terhadap pekerja.

Berdasarkan temuan penelitian di atas penulis menyarankan bahwa hasil penelitian, teori dengan sudut pandang, dan penelitian sebelumnya yaitu Kualitas. Guru, Motivasi dan Iklim Kerja mempunyai pengaruh yang positif dan penting terhadap keberhasilan guru pada saat yang bersamaan 


\section{CONCLUSIONS}

\section{Kesimpulan}

Berdasarkan hasil penelitian dan pembahasan yang telah dikemukakan sebelumnya, maka dapat diambil kesimpulan dari penelitian mengenai pengaruh Kompetensi Guru, Motivasi dan Lingkungan Kerja berpengaruh terhadap Kinerja Guru pada SMP Kartika 1-2 Medan dengan jumlah sampel 31 guru adalah sebagaiberikut :

1. Ada pengaruh Kompetensi Guru terhadap Kinerja Guru pada SMP Kartika1-2 Medan.

2. Ada pengaruh Motivasi terhadap Kinerja Guru pada SMP Kartika 1-2 Medan.

3. Ada pengaruh Lingkungan Kerja terhadap Kinerja Guru pada SMP Kartika1-2 Medan. Ada pengaruh Kompetensi Guru, Motivasi , Lingkungan Kerja secara simultan terhadap Kinerja Guru pada SMP Kartika 1-2 Medan.

\section{REFERENCES}

A.A Anwar Mangkunegara.(2011). Manajemen Sumber Daya Manusia. Bandung: PT.Remaja Kosda Karya.

Andi Veny Anggreini M. (2019) Pengaruh Kompetensi, Motivasi dan Lingkungan Kerja Terhadap Kinerja Pegawai Pada Kantor Dinas Energy dan Sumber Daya Mineral Donggala.

Andikan Sulistyo Rini, dkk (2018) Pengaruh Kompetensi, Motivasi dan Lingkungan Kerja Terhadap Kinerja Karyawan PT Pos Indonesia ( Peesero) Cabang Surakarta.

Arianto, D. A. N. (2013). Pengaruh Kedisiplinan, Lingkungan Kerja dan Budaya Kerja Terhadap Kinerja Tenaga Pengajar. Jurnal Economia, 9(2), 191-200.

Bukhari, Sjahril Effendi Pasaribu. (2019) Pengaruh Motivasi, Kompetensi, Dan Lingkungan Kerja Terhadap Kinerja.

Danim, Sudarwan. (2010). Kepemimpinan Pendidikan (Kepemimpinan Jenius IQ+EQ, Etika, Perilaku Motivasional, dan Mitos). Bandung: Alfabeta CV.

Gibson, James L., John M. Ivancevich \& James H. Donnelly, Jr. (2010). Organisasi, Perilaku, Struktur, Proses. (Alih Bahasa Nunuk Adiarni). Jakarta: Binarupa Aksara. 
Hasibuan, Melayu S.P. (2014). Manajemen Sumber Daya Manusia.Jakarta : Bumi Aksara.

Jandhika Hendrianto. (2015). Pengaruh Motivasi Kerja Dan Kompensasi Terhadap Kinerja Karyawan PT X. Jurnal Ilmiah AGORA Vol. 3, No. 2, (2015).

Jufrizen, J. (2018). Peran Motivasi Kerja Dalam Memoderasi Pengaruh Kompensasi Dan Disiplin Kerja Terhadap Kinerja Karyawan. Prosiding: The National Conferences Management and Business (NCMAB) 2018, 4

424. https://publikasiilmiah.ums.ac.id/xmlui/handle/11617/9974.

Juliandi, A., Irfan, I., \& Manurung, S. (2015). Metodologi Penelitian Bisnis Konsep \& Aplikasi. Medan: UMSU Press.

Maju Siregar (2019). Kompetensi, Motivasi Kerja dan Lingkungan Kerja Terhadap Kinerja Guru SMA 18 Medan.

Mangkunegara, Anwar Prabu. (2011). Manajemen Sumber Daya Manusia Perusahaan. Bandung: Remaja Rosdakarya.

Moeheriono.(2012). Pengukuran Kinerja Berbasis Kompetensi. Surabaya: Ghalia Indonesia.

Moekijat.(2010). Manajemen Sumber Daya Manusia.Mandar, Bandung. Muhammad Riyanda (2017) Pengaruh Kompetensi dan Disiplin Kerja Terhadap Kinerja.

Rivai, Veithzal. (2015). Manajemen Sumber Daya Manusia untuk Perusahaan (Teori dan Praktek).Jakarta : Murai Kencana.

Saud. 2010. Jurnal Teknologi Pendidikan Vol. 19, No. 1, April 2017 ... profesi guru. Kata kunci: kinerja penilaian, kompetensi guru, sikap profesi guru ... pekerjaan atau urusan tertentu.

Sedarmayanti.(2014). Manajemen Sumber Daya Manusia, Reformasi Birokrasi dan Manajemen Pegawai Negeri Sipil. Bandung: PT. Refika Aditama.

Siagian, Sondang P. (2010). Manajemen Sumber Daya Manusia. Jakarta: Bumi Aksara Simamora, Henry. (2010) Manajemen Sumber Daya Manusia.Yogyakarta: STIE YKPN.

Sugiyono. (2017). Metode Penelitian Bisnis (Dua Belas). Bandung :Alfabeta Sugiyono.(2011). Metode Penelitian Bisnis. Bandung :Alfabeta 
Tanto Wijaya. (2015). Pengaruh Motivasi Dan Kompensasi Terhadap Kinerja Karyawan Pada PT Sinar Jaya Abadi Bersama. Jurnal ilmiah AGORA Vol. 3, No. 2, (2015)

Tb.Sjafri Mangkuprawira. (2011). Manajemen Sumber Daya Manusia Strategik Cet.1 Ed.2.Bogor: Penerbit Galih Indonesia.

Usman Moh. Uzer. (2010) Menjadi Guru Profesional. Remaja Rosdakarya, Bandung. 